$\checkmark$ Research Square

\title{
Interstitial Lung Disease and Partial Resection are Poor Prognostic Factors for pStage IA NSCLC: A Retrospective Study
}

Nozomu Motono ( $\square$ motono@kanazawa-med.ac.jp )

Kanazawa Medical University

Masahito Ishikawa

Kanazawa Medical University

Shun Iwai

Kanazawa Medical University

Aika Yamagata

Kanazawa Medical University

Yoshihito lijima

Kanazawa Medical University

Hidetaka Uramoto

Kanazawa Medical University

\section{Research Article}

Keywords: early stage, non-small cell lung cancer, interstitial lung disease, partial resection

Posted Date: September 22nd, 2021

DOI: https://doi.org/10.21203/rs.3.rs-793480/v2

License: (c) (i) This work is licensed under a Creative Commons Attribution 4.0 International License.

Read Full License 


\section{Abstract}

Introduction: The prognostic factors in patients who underwent pulmonary resection with early stage nonsmall cell lung cancer (NSCLC) have not been elucidated.

Materials and methods: Clinical data of 540 patients with pathological stage IA NSCLC were analyzed. Patient factors such as sex, age, comorbidities, carcinoembryonic antigen (CEA), smoking history, and operative aspects such as operative approach and operative procedures were collected and analyzed.

Results: There were significant prognostic differences according to the interstitial lung disease $(p<0.0001)$, CEA $(p=0.007)$, and partial resection $(p=0.002)$ in the relapse-free survival (RFS). There were significant prognostic differences according to the interstitial lung disease $(p=0.0015)$, CEA $(p<$ $0.0001)$, and smoking history ( $p=0.0003$ ) in the overall survival (OS). Interstitial lung disease (hazard ratio [HR]: 7.725, $p=0.003$ ), CEA (HR: 1.923, $p=0.045$ ), and operative procedure (HR: 2.086, $p=0.025$ ) were risk factors for RFS in a multivariate analysis. Smoking history (HR: 2.539, $p=0.002)$ and CEA (HR: $2.464, p=0.002$ ) were risk factors for OS in a multivariate analysis.

Conclusion: Interstitial lung disease, CEA, and operative procedure were risk factors for RFS, while smoking history and CEA were risk factors for OS.

\section{Introduction}

Lung cancer is the leading cause of cancer-related mortality worldwide, with non-small cell lung cancer (NSCLC) accounting for more than $80 \%$ of all cases ${ }^{1}$. Although the standard treatment for early stage NSCLC is lobectomy combined with systematic lymph node dissection, sublobar resection for early stage NSCLC leads toward a more favorable prognosis than lobectomy 2,3 .

Video-assisted thoracic surgery (VATS) for patients with NSCLC has been widely adopted, and various studies have reported the advantages of this approach ${ }^{4-7}$. These reports revealed that VATS is associated with minimal pain, shorter hospital stay, less reduction in the inflammatory immune response, and maintenance of postoperative respiratory function when compared with thoracotomy. However, the relationship between the prognosis and operative approaches such as VATS in NSCLC patients who underwent pulmonary resection has not been elucidated.

Several prognostic factors in patients with early stage NSCLC have been reported ${ }^{8-17}$. Although the prognosis of stage IA NSCLC is considered good compared with the advanced stage, age, gender, carcinoembryonic antigen (CEA), tumor size, operative procedure, surgical margin, pleural invasion, lymphatic invasion, histological type, and presence of combined pulmonary fibrosis and emphysema (CPFE) have been reported as prognostic factors in patients with early stage NSCLC.

In the present study, we retrospectively evaluated the prognostic factors in pathological stage IA NCSLC patients who underwent pulmonary resection. 


\section{Results}

\section{Patient characteristics}

The clinicopathological characteristics of the 540 NSCLC patients with pathological stage IA are listed in Table 1. Among these, 310 were men and the median age was 70.6 years. The median Brinkman index was 400 . Altogether, 310 patients had comorbidities including 7 with interstitial lung disease, 107 with malignant disease, and 35 with angina pectoris. The median CEA was $3.0 \mathrm{ng} / \mathrm{mL}$. The median \%VC was $100.7 \%$ and the median $\mathrm{FEV}_{1} \%$ was $73.9 \%$. The pulmonary lobes resected for NSCLC included the right upper lobe in 169 patients, right middle lobe in 33, right lower lobe in 118, left upper lobe in 130, and left lower lobe in 94 patients. 
Table 1

Patient characteristics $(n=540)$

\section{Gender (Male / Female)}

Age (year), median (range)

\section{Comorbidity}

Interstitial lung disease (\%)

Malignant disease (\%)

Angina pectoris (\%)

Smoking index, median (range)

CEA (ng/ml), median (range)

$\% \mathrm{VC}$, median (range)

$\mathrm{FEV}_{1} \%$, median (range)

Lobe of lung cancer

$\mathrm{RU} / \mathrm{RM} / \mathrm{RL} / \mathrm{LU} / \mathrm{LL}$

Operative approach

RATS / C-VATS / H-VATS / Open

\section{Operative procedure}

Part / Seg / Lob

Histology (Ad / Sq / LCNEC / Pleo / AdSq / Large / Carcinoid)

Lymphatic invasion (present/absent)

Vascular invasion (present/absent)

Differentiation (G1 / 2 / 3 / 4)

Postoperative complication

Clavien-Dindo grade (0 / 1 / 2 / 3a / 3b)

Thirty-day mortality (\%)

Ninety-day mortality (\%)
10 / 244 / 267 / 19

$310 / 230$

$70.6(22-92)$

$319(59.1 \%)$

$7(1.3 \%)$

$107(19.8 \%)$

$35(6.5 \%)$

$400(0-3250)$

$3.0(0.5-44)$

$100.7(53.4-177.7)$

$73.9(30.5-99.4)$

165 / 33 / 118 / 130 / 94

$131 / 57 / 352$

454 / 60 / 13 / 3 / 4 / 1 / 5

92 / 448

$136 / 404$

240 / 243 / 45 / 12

$127(23.5 \%)$

413 / 0 / 48 / 76 / 3

$1(0.05 \%)$

$1(0.05 \%)$

CEA; carcinoembryonic antigen, \%VC; vital capacity, FEV1\%; forced expiratory volume \% in one second, RU; right upper, RM; right middle, RL; right lower, LU; left upper, LL; left lower, RATS; Robotassisted Thoracic Surgery, C; complete, VATS; video-assisted thoracic surgery, H; hybrid, Part; partial resection, Seg; segmentectomy, Lob; lobectomy, Ad; adenocarcinoma, Sq; squamous cell carcinoma, LCNEC; large cell neuroendocrine carcinoma, Pleo; pleomorphic carcinoma, AdSq; adenosquamous cell carcinoma, Large; large cell carcinoma, G;grade 
CEA; carcinoembryonic antigen, \%VC; vital capacity, FEV1\%; forced expiratory volume \% in one second, RU; right upper, RM; right middle, RL; right lower, LU; left upper, LL; left lower, RATS; Robotassisted Thoracic Surgery, C; complete, VATS; video-assisted thoracic surgery, $\mathrm{H}$; hybrid, Part; partial resection, Seg; segmentectomy, Lob; lobectomy, Ad; adenocarcinoma, Sq; squamous cell carcinoma, LCNEC; large cell neuroendocrine carcinoma, Pleo; pleomorphic carcinoma, AdSq; adenosquamous cell carcinoma, Large; large cell carcinoma, G;grade

\section{Operative factors}

C-VATS was performed in 244 patients, H-VATS in 267 patients, RATS in 10 patients, and open thoracotomy in 19 patients. Partial resection was performed in 131 patients, segmentectomy in 57 , and lobectomy in 352.

\section{Pathological factors}

Histological types were divided into 7 types as follows: 454 patients were diagnosed as adenocarcinoma, 60 patients as squamous cell carcinoma, 13 as large cell neuroendocrine carcinoma, 3 as pleomorphic carcinoma, 4 as adenosquamous cell carcinoma, 1 as large cell carcinoma, and 5 as carcinoid.

Lymphatic invasion was present in 92 patients and vascular invasion was present in 136 patients. Grade of differentiation was divided into 4 categories: G1 in 240 patients, G2 in 243 patients, G3 in 45 patients, and $\mathrm{G} 4$ in 12 patients.

\section{Postoperative complications}

Postoperative complications were observed in 127 patients (23.5\%). Clavien-Dindo grade II complications were noted in 48 patients, grade IIla in 76, and grade IIlb in 3. Major postoperative complications included air leakage in 65 patients, arrhythmia in 21 (atrial fibrillation in 19 patients and paroxysmal supraventricular tachycardia in 2 patients), atelectasis in 16, pneumonia in 12, fever in 4 , chylothorax in 2, and cerebral infarction in 2. Serious postoperative complications included postoperative bleeding in 1 patient, postoperative respiratory failure in 1 patient, and right middle lobe congestion in 1 patient. Two patients improved with surgery and 1 patient was ameliorated by a ventilator. The median duration of postoperative hospital stay was 10 days, and thirty-day and ninety-day mortality was $0.05 \%$ and $0.05 \%$, respectively.

\section{Survival analyses}

Relapse free survival (RFS) is shown in Fig. 1. There were significant prognostic differences according to the interstitial lung disease $(p<0.0001), C E A(p=0.007)$, and partial resection $(p=0.002)$. Overall survival (OS) is shown in Fig. 2. There were significant prognostic differences according to the interstitial lung disease $(p=0.0015)$, CEA $(p<0.0001)$ and smoking history $(p=0.0003)$.

\section{Univariate and multivariate analysis}


The relationship between clinicopathological patient characteristics or operative factors and RFS was analyzed (Table 2$)$. Interstitial lung disease $(p<0.0001)$, CEA $(p=0.006)$, and operative procedure $(p=$ $0.002)$ were significant differences in the univariate analysis. Furthermore, interstitial lung disease (hazard ratio [HR]: 7.725, 95\% confidence interval [Cl]: 2.144-21.776, $p=0.003$ ), CEA (HR: 1.923, 95\% Cl: $1.015-3.518, p=0.045)$, and operative procedure (HR: 2.086, 95\% Cl: $1.100-3.825, p=0.025)$ were risk factors for RFS in the multivariate analysis. 
Table 2

Univariate and multivariate analyses of clinicopathological factors in pathological stage IA NSCLC patients

\begin{tabular}{|c|c|c|c|c|c|c|}
\hline \multirow[t]{2}{*}{ Variables } & & \multirow{2}{*}{$\begin{array}{l}\text { 5-year } \\
\text { RFS (\%) }\end{array}$} & \multirow{2}{*}{$\begin{array}{l}\text { Univariate } p \\
\text { value }\end{array}$} & \multicolumn{3}{|c|}{ Multivariate analysis } \\
\hline & & & & HR & $95 \% \mathrm{Cl}$ & $\begin{array}{l}\mathrm{p} \\
\text { value }\end{array}$ \\
\hline \multirow[t]{2}{*}{ Gender } & Male & 86.3 & 0.676 & & & \\
\hline & Female & 88.9 & & & & \\
\hline \multirow[t]{2}{*}{ Age } & $\leq 75$ year & 85.7 & 0.175 & & & \\
\hline & $>75$ year & 90.8 & & & & \\
\hline \multicolumn{7}{|l|}{ Comorbidity } \\
\hline \multirow[t]{2}{*}{ Malignant disease } & Present & 90.5 & 0.913 & & & \\
\hline & Absent & 86.8 & & & & \\
\hline \multirow[t]{2}{*}{$\begin{array}{l}\text { Interstitial lung } \\
\text { disease }\end{array}$} & Present & 33.3 & $<0.0001$ & 7.725 & $\begin{array}{l}2.144- \\
21.7776\end{array}$ & 0.003 \\
\hline & Absent & 88.2 & & & & \\
\hline \multirow[t]{2}{*}{ Angina pectoris } & Present & 88.7 & 0.651 & & & \\
\hline & Absent & 87.3 & & & & \\
\hline \multirow[t]{2}{*}{ Smoking history } & Present & 86.3 & 0.140 & & & \\
\hline & Absent & 88.7 & & & & \\
\hline \multirow[t]{2}{*}{$\% \mathrm{VC}$} & $<80$ & 92.9 & 0.611 & & & \\
\hline & $\geq 80$ & 87.0 & & & & \\
\hline \multirow[t]{2}{*}{$\mathrm{FEV}_{1} \%$} & $<70$ & 85.5 & 0.209 & & & \\
\hline & $\geq 70$ & 88.2 & & & & \\
\hline \multirow[t]{2}{*}{ CEA } & $>5 \mathrm{ng} / \mathrm{ml}$ & 79.0 & 0.006 & 1.923 & $\begin{array}{l}1.015- \\
3.518\end{array}$ & 0.045 \\
\hline & $\leq 5 \mathrm{ng} / \mathrm{ml}$ & 89.9 & & & & \\
\hline \multirow[t]{2}{*}{ Operative approach } & C-VATS or RATS & 82.4 & 0.331 & & & \\
\hline & H-VATS or Open & 88.7 & & & & \\
\hline
\end{tabular}

RFS; relapse free survival, HR; hazard ratio, Cl; confidence interval, \%VC; vital capacity, FEV1\%; forced expiratory volume \% in one second, CEA; carcinoembryonic antigen, C; complete, VATS; video-assisted thoracic surgery, RATS; Robot-assisted Thoracic Surgery, H; hybrid, G; grade 


\begin{tabular}{|c|c|c|c|c|c|c|}
\hline \multirow{2}{*}{$\begin{array}{l}\text { Variables } \\
\begin{array}{l}\text { Operative } \\
\text { procedure }\end{array}\end{array}$} & \multirow[b]{2}{*}{ Partial resection } & \multirow{2}{*}{$\begin{array}{l}\text { 5-year } \\
\text { RFS (\%) } \\
81.1\end{array}$} & \multirow{2}{*}{$\begin{array}{l}\text { Univariate } p \\
\text { value } \\
0.002\end{array}$} & \multicolumn{3}{|c|}{ Multivariate analysis } \\
\hline & & & & 2.086 & $\begin{array}{l}1.100- \\
3.825\end{array}$ & 0.025 \\
\hline & $\begin{array}{l}\text { Segmentectomy } \\
\text { or more }\end{array}$ & 89.2 & & & & \\
\hline \multirow{2}{*}{$\begin{array}{l}\text { Postoperative } \\
\text { complication }\end{array}$} & Present & 84.6 & 0.641 & & & \\
\hline & Absent & 88.1 & & & & \\
\hline \multirow[t]{2}{*}{ Lymphatic invasion } & Present & 81.9 & 0.086 & & & \\
\hline & Absent & 88.6 & & & & \\
\hline \multirow[t]{2}{*}{ Vascular invasion } & Present & 82.3 & 0.120 & & & \\
\hline & Absent & 89.2 & & & & \\
\hline \multirow[t]{2}{*}{ Differentiation } & $\mathrm{G} 1$ or 2 & 85.4 & 0.101 & & & \\
\hline & G3 or 4 & 82.6 & & & & \\
\hline $\begin{array}{l}\text { RFS; relapse free sur } \\
\text { expiratory volume \% } \\
\text { thoracic surgery, RA }\end{array}$ & $\begin{array}{l}\text { ival, HR; hazard rati } \\
\text { ? one second, CEA; } \\
\text {; Robot-assisted Ti }\end{array}$ & $\begin{array}{l}\text { Cl; confider } \\
\text { cinoembry } \\
\text { acic Surge }\end{array}$ & $\begin{array}{l}\text { interval, \%VC; } \\
\text { ic antigen, C; c } \\
\text { H; hybrid, G; gr }\end{array}$ & $\begin{array}{l}\text { tal capa } \\
\text { mplete, }\end{array}$ & $\begin{array}{l}\text { ity, FEV1\% } \\
\text { ATS; videc }\end{array}$ & $\begin{array}{l}\text { orced } \\
\text { sisted }\end{array}$ \\
\hline
\end{tabular}

The relationship between clinicopathological patient characteristics or operative factors and OS was analyzed (Table 3$)$. Interstitial lung disease $(p=0.0015)$, smoking history $(p=0.0003)$, and CEA $(p<$ 0.0001 ) were significant differences in the univariate analysis. Furthermore, smoking history (HR: 2.539, 95\% Cl: $1.372-5.002, \mathrm{p}=0.002)$ and CEA (HR: $2.464,95 \% \mathrm{Cl}: 1.389-4.317, \mathrm{p}=0.002)$ were considered as risk factors for OS in the multivariate analysis. 
Table 3

Univariate and multivariate analyses of clinicopathological factors in pathological stage IA NSCLC patients

\begin{tabular}{|c|c|c|c|c|c|c|}
\hline \multirow[t]{2}{*}{ Variables } & & \multirow{2}{*}{$\begin{array}{l}\text { 5-year } \\
\text { OS (\%) }\end{array}$} & \multirow{2}{*}{$\begin{array}{l}\text { Univariate } p \\
\text { value }\end{array}$} & \multicolumn{3}{|c|}{ Multivariate analysis } \\
\hline & & & & HR & $95 \% \mathrm{Cl}$ & $\begin{array}{l}\mathrm{p} \\
\text { value }\end{array}$ \\
\hline \multirow[t]{2}{*}{ Gender } & Male & 82.0 & 0.344 & & & \\
\hline & Female & 86.6 & & & & \\
\hline \multirow[t]{2}{*}{ Age } & $\leq 75$ year & 82.1 & 0.276 & & & \\
\hline & $>75$ year & 87.2 & & & & \\
\hline \multicolumn{7}{|l|}{ Comorbidity } \\
\hline \multirow[t]{2}{*}{ Malignant disease } & Present & 83.1 & 0.913 & & & \\
\hline & Absent & 83.7 & & & & \\
\hline \multirow[t]{2}{*}{$\begin{array}{l}\text { Interstitial lung } \\
\text { disease }\end{array}$} & Present & 62.5 & 0.0015 & 3.431 & $\begin{array}{l}0.54- \\
11.931\end{array}$ & 0.158 \\
\hline & Absent & 84.2 & & & & \\
\hline \multirow[t]{2}{*}{ Angina pectoris } & Present & 91.4 & 0.575 & & & \\
\hline & Absent & 83.4 & & & & \\
\hline \multirow[t]{2}{*}{ Smoking history } & Present & 77.2 & 0.0003 & 2.539 & $\begin{array}{l}1.372- \\
5.002\end{array}$ & 0.002 \\
\hline & Absent & 91.6 & & & & \\
\hline \multirow[t]{2}{*}{$\% \mathrm{VC}$} & $<80$ & 89.6 & 0.969 & & & \\
\hline & $\geq 80$ & 83.4 & & & & \\
\hline \multirow[t]{2}{*}{$\mathrm{FEV}_{1} \%$} & $<70$ & 81.6 & 0.293 & & & \\
\hline & $\geq 70$ & 84.7 & & & & \\
\hline \multirow[t]{2}{*}{ CEA } & $>5 \mathrm{ng} / \mathrm{ml}$ & 68.6 & $<0.0001$ & 2.464 & $\begin{array}{l}1.389- \\
4.317\end{array}$ & 0.002 \\
\hline & $\leq 5 \mathrm{ng} / \mathrm{ml}$ & 88.5 & & & & \\
\hline \multirow[t]{2}{*}{ Operative approach } & C-VATS or RATS & 78.1 & 0.122 & & & \\
\hline & H-VATS or Open & 85.4 & & & & \\
\hline
\end{tabular}




\begin{tabular}{|c|c|c|c|c|}
\hline Variables & & $\begin{array}{l}\text { 5-year } \\
\text { OS (\%) }\end{array}$ & $\begin{array}{l}\text { Univariate } p \\
\text { value }\end{array}$ & Multivariate analysis \\
\hline \multirow[t]{2}{*}{ Operative procedure } & Partial resection & 90.0 & 0.942 & \\
\hline & $\begin{array}{l}\text { Segmentectomy } \\
\text { or more }\end{array}$ & 82.7 & & \\
\hline \multirow{2}{*}{$\begin{array}{l}\text { Postoperative } \\
\text { complication }\end{array}$} & Present & 75.6 & 0.098 & \\
\hline & Absent & 86.3 & & \\
\hline \multirow[t]{2}{*}{ Lymphatic invasion } & Present & 76.8 & 0.661 & \\
\hline & Absent & 85.5 & & \\
\hline \multirow[t]{2}{*}{ Vascular invasion } & Present & 78.6 & 0.499 & \\
\hline & Absent & 85.6 & & \\
\hline \multirow[t]{2}{*}{ Differentiation } & $\mathrm{G} 1$ or 2 & 84.5 & 0.201 & \\
\hline & G3 or 4 & 78.0 & & \\
\hline $\begin{array}{l}\text { OS; overall survival, } \\
\text { expiratory volume \% } \\
\text { thoracic surgery, RAT }\end{array}$ & $\begin{array}{l}\text { hazard ratio, } \mathrm{Cl} ; \mathrm{c} \\
\text { one second, CEA; } \\
\text { Robot-assisted Tr }\end{array}$ & $\begin{array}{l}\text { dence in } \\
\text { inoembr } \\
\text { cic Surg }\end{array}$ & $\begin{array}{l}\text { al, \%VC; vital c } \\
\text { c antigen, C; c } \\
\text { l; hybrid, G; gr }\end{array}$ & $\begin{array}{l}\text { acity, FEV1\%; forced } \\
\text { iplete, VATS; video-assi }\end{array}$ \\
\hline
\end{tabular}

\section{Discussion}

In the present study, we analyzed the prognostic factors for inpatients who underwent pulmonary resection for pathological stage IA NSCLC. This study demonstrated that interstitial lung disease, CEA, and partial resection were significant prognostic factors for RFS, whereas CEA and smoking history were significant prognostic factors for OS. Although survival was similar for patients treated with limited resection to that of patients receiving lobectomy in some reports ${ }^{18-19}$, partial resection was reported as the risk factor for locoregional recurrence in other reports ${ }^{8,20-22}$. Because these reports showed a trend toward a higher locoregional recurrence rate in patients who underwent wedge resection compared with segmentectomy $8,20-22$, segmentectomy should be the more suitable surgical procedure in patients being considered for sublobar resection.

We previously reported that the presence of CPFE was a statistically significant predictor of recurrence for patients with clinical stage I NSCLC ${ }^{12}$. Furthermore, lung cancer patients with idiopathic pulmonary fibrosis (IPF) showed a statistically significant worse mortality rate compared to lung cancer patients without IPF ${ }^{23}$. IPF is the most frequent and severe type of idiopathic interstitial pneumonia and has a median survival of approximately 3 years after diagnosis ${ }^{24}$. In the treatment of lung cancer patients with IPF, physicians are reluctant to treat lung cancer because of the poor prognosis ${ }^{25}$. GAP (gender [G], age $[\mathrm{A}]$, and two lung physiology variables [P]) staging system has been used to predict the mortality and the 
timing of lung transplantation in IPF patients ${ }^{26}$. Although beneficial treatment modalities were not found at GAP stage II/III, active therapies such as surgery for lung cancer patients with IPF in GAP stage I are recommended in the previous study ${ }^{27}$. Therefore, the benefit of surgery for NSCLC patients with interstitial lung disease should be carefully evaluated by using the GAP staging system.

Reportedly, VATS is associated with minimal pain, less reduction in the inflammatory immune response, and maintenance of postoperative respiratory function when compared with thoracotomy. Therefore, VATS is considered as a less invasive procedure ${ }^{4-7}$. However, the relationship between prognosis and operative approaches such as VATS or RATS in NSCLC patients who have undergone pulmonary resection has not been elucidated. Our previous study revealed that operative invasiveness does not affect the prognosis of patients with NSCLC ${ }^{28}$. Because VATS and RATS were not prognostic factors in the present study, the operative approach therefore does not influence the prognosis of NSCLC patients.

The present study has several limitations. First, the study was retrospective in nature and potentially involved unobserved cofounding and selection biases. Second, the present study was performed at a single institution, and the study population was relatively small.

\section{Conclusion}

Our findings described the prognostic factors in pathological stage IA NCSLC patients who underwent pulmonary resection. This study revealed that interstitial lung disease, CEA, and operative procedure were risk factors for RFS while smoking history and CEA were risk factors for OS. These results thereby postulate that segmentectomy is a more suitable surgical procedure for patients who are being considered for sublobar resection. Furthermore, the benefit of surgery for NSCLC patients with interstitial lung disease should be carefully evaluated.

\section{Materials And Methods}

\section{Patients}

Nine hundred fifty-six NSCLC patients who underwent pulmonary resection at Kanazawa Medical University between January 2002 and March 2020 and 540 patients with pathological stage IA were enrolled in this retrospective study.

Data including clinicopathological factors such as gender, age, comorbidities, smoking history, respiratory function, CEA, lung cancer lobe involvement, histological type, lymphatic invasion, vascular invasion, and differentiation were collected. Comorbidities were divided into three categories: interstitial lung disease, malignant disease, and angina pectoris. Smoking history was assessed using the Brinkman index, which is calculated by multiplying the number of cigarettes smoked per day by the number of years the subject

has been smoking ${ }^{29}$. Respiratory function parameters such as percent-predicted vital capacity (\%VC) and forced expiratory volume in 1 second as a percentage of forced vital capacity $\left(\mathrm{FEV}_{1} \%\right)$ were collected. 


\section{Operative factors}

The operative approach was divided into four categories: complete VATS (C-VATS, surgery performed only to provide a monitoring view), hybrid VATS (H-VATS, surgery combined with direct vision without rib spreading), robot-assisted thoracic surgery (RATS), and open thoracotomy. The operative procedure was stratified into three categories: partial resection, segmentectomy, and lobectomy.

\section{Postoperative complications}

Postoperative complications were categorized into five grades according to the Clavien-Dindo classification system ${ }^{15}$. The Clavien-Dindo classification was established in 1992. It is a simple and feasible grading system for all types of postoperative complications ${ }^{16}$. In 2004, it was modified to allow grading of life-threatening complications and long-term disability caused by a complication ${ }^{17}$. This revised version has defined five grades of severity with subgrades (grades I, II, IIla, IIIb, IVa, IVb, and V), and the suffix " $d$ " (for "disability") is used to denote any postoperative impairment. This modified version of the Clavien-Dindo classification has been widely used in clinical practice.

\section{Statistical analyses}

We used Pearson's chi-square test of independence to compare the frequencies of the variables. Cumulative survival was calculated by the Kaplan-Meier method and survival curves were compared using the Logrank test. Risk factors associated with postoperative complications were analyzed using logistic regression analysis. All statistical analyzes were performed on both sides and the statistical significance was set to $p<0.05$. Statistical analysis was performed using JMP software program version 13.2 (SAS Institute Inc., Cary, NC, USA).

This study was conducted in accordance with the principles of the Declaration of Helsinki. The institutional review committee of Kanazawa Medical University approved the protocol (approval number: 1392), and all patients gave written informed consent

\section{Abbreviations}

NSCLC

non-small cell lung cancer, VATS:video-assisted thoracic surgery, CEA:carcinoembryonic antigen, CPFE:combined pulmonary fibrosis and emphysema, \%VC:percent-predicted vital capacity, $\mathrm{FEV}_{1} \%$ :forced expiratory volume in 1 second as a percentage of forced vital capacity, RATS:robot-assisted thoracic surgery, RFS:relapse free survival, OS:overall survival, HR:hazard ratio, Cl:confidence interval.

\section{Declarations}

Ethics approval and consent to participate 
The present study was conducted in accordance with the amended Declaration of Helsinki. The Institutional Review Boards of Kanazawa Medical University approved the protocol (approval number: 1392), and written informed consent was obtained from all of the patients.

\section{Consent for publication}

Not applicable.

\section{Availability of data and materials}

The datasets generated and/or analysed during the current study are not publicly available due to [our institutional restrictions e.g. them containing information that could compromise research participant privacy/consent], but are available from the corresponding author on reasonable request.

\section{Competing interests}

The authors declare that they have no competing interests.

\section{Funding}

This study has not been funded.

\section{Author's contributions}

N. M. performed the research, collected and analyzed the data and wrote the paper. M.I., S. I., A.Y., and Y.I. contributed to sample collection. H. U. contributed to supervision of this study and revision of the manuscript. All authors have read and approved the manuscript, and ensure that this is the case.

\section{Acknowledgements}

Not applicable.

\section{Competing interests}

The authors declare that they have no competing interests.

\section{References}

1. Siegel, R. L., Miller, K. D. \& Jemal, A. Cancer statistics, 2018. CA Cancer J Clin, 68, 7-30 (2018).

2. Berfield, K. S. \& Wood, D. E. Sublobar resection for stage IA non-small cell lung cancer. J Thorac Dis, 9, S208-10 (2017).

3. Sakurai, H. \& Asamura, H. Sublobar resection for early-stage lung cancer. Trans/ Lung Cancer Res, 3 , 164-172 (2014). 
4. Mckenna, R. J. Jr, Houck, W. \& Fuller, C. B. Video-assisted thoracic surgery lobectomy: experience with 1,100 cases. Ann Thorac Surg, 81, 421-426 (2006).

5. Flores, R. M. et al. Lobectomy by video-assisted surgery (VATS) versus thoracotomy for lung cancer. J Thorac Cardiovasc Surg, 138, 11-18 (2009).

6. Whitson, B. A., Groth, S. S., Duval, S. J., Swanson, S. J. \& Maddaus, M. A. Surgery for early-stage nonsmall cell lung cancer: a systematic review of the video-assisted thoracoscopic surgery versus thoracotomy approaches to lobectomy. Ann Thorac Surg, 86, 2008-2018 (2008).

7. Sakuraba, M. et al. Video-assisted thoracoscopic lobectomy vs. conventional lobectomy via open thoracotomy in patients with clinical stage IA non-small cell lung carcinoma. Interact Cardiovasc Thorac Surg, 6, 614-617 (2007).

8. Koike, T., Koike, T., Yoshiya, K., Tsuchida, M. \& Toyabe, S. Risk factor analysis of locoregional recurrence after sublobar resection in patients with clinical stage IA non-small cell lung cancer. $J$ Thorac Cardiovasc Surg, 146, 372-378 (2013).

9. Shimada, Y. et al. Predictive factors of pathologically proven noninvasive tumor characteristics in T1aNOMO peripheral non-small cell lung cancer. CHEST, 141, 1003-1009 (2012).

10. Koike, T., Koike, T., Yamato, Y., Yoshiya, K. \& Toyabe, S. Predictive risk factors for mediastinal lymph node metastasis in clinical stage IA non-small-cell lung cancer patients. J Thorac Oncol, 7, 12461251 (2012).

11. Koike, T., Tsuchiya, R., Goya, T., Sohara, Y. \& Miyaoka, E. Prognostic factors in 3315 completely resected case of clinical stage I non-small cell lung cancer in Japan. $J$ Thorac Oncol, 2, 408-413 (2007).

12. Maeda, R. et al. Combined pulmonary fibrosis and emphysema predicts recurrence following surgery in patients with stage I non-small cell lung cancer. Med Oncol, 35, 31 (2018).

13. Tas, F., Ciftci, R., Kilic, L. \& Karabulut, S. Age is a prognostic factor affecting survival in lung cancer patients. Oncol Lett, 6, 1507-1513 (2013).

14. Sayar, A. et al. Nonanatomic prognostic factors in resected nonsmall cell lung carcinoma: the importance of peripheral invasion as a new prognostic marker. Ann Thorac Surg, 77, 421-425 (2004).

15. Suzuki, K. et al. Prognostic factors in clinical stage I non-small cell lung cancer. Ann Thorac Surg, 67, 927-932 (1999).

16. Rena, O. et al. Stage I non-small cell lung carcinoma: really an early stage? Eur J Crdiothorac Surg, 20, 378-384 (2001).

17. Hug, J. J. et al. Prognostic factors in resected stage I non-small cell lung cancer with a diameter of 3 $\mathrm{cm}$ or less: visceral pleural invasion did not influence overall and disease-free survival. $J$ Thorac Cardiovasc Surg, 134, 638-643 (2007).

18. Nakamura, H., Kawasaki, N., Taguchi, M. \& Kabasawa, K. Survival following lobectomy vs limited resection for stage I lung cancer: a meta-analysis. British Journal of Cancer, 92, 1033-1037 (2005). 
19. Griffin, J. P., Eastridge, C. E., Tolley, E. A. \& Pate, J. W. Wedge Resection for non-small cell lung cancer in patients with pulmonary insufficiency: prospective ten-year survival. J Thorac Oncol, 1, 960-964 (2006).

20. Ginsberg, R. J. \& Rubinstein, L. V. Randomized trial of lobectomy versus limited resection for T1 N0 non-small cell lung cancer. Lung Cancer Study Group. Ann Thorac Surg, 60, 615-623 (1995).

21. Okada, M. et al. Effect of tumor size on prognosis in patients with non-small cell lung cancer: the role of segmentectomy as a type of lesser resection. J Thorac Cardiovasc Surg, 129, 87-93 (2005).

22. El-Sherif, A. et al. Margin and local recurrence after sublobar resection of non-small cell lung cancer. Ann Surg Oncol, 14, 2400-2405 (2007).

23. Yoon, J. H. et al. Characteristics of lung cancer among patients with idiopathic pulmonary fibrosis and interstitial lung disease - analysis of institutional and population data. Respir Res, 19, 195 (2018).

24. Raghu, G. et al. An official ATS/ERS/JRS/ALAT statement: idiopathic pulmonary fibrosis: evidencebased guidelines for diagnosis and management. Am J Respir Crit Care Med, 183, 788-824 (2011).

25. Barczi, E. et al. Impact of interstitial lung disease and simultaneous lung cancer on therapeutic possibilities and survival. Thorac Cancer, 11, 1911-1917 (2020).

26. Ley, B. et al. A multidimensional index and staging system for idiopathic pulmonary fibrosis. Ann Intern Med, 156, 684-691 (2012).

27. Han, S. Y. et al. Prognosis of non-small-cell lung cancer in patients with idiopathic pulmonary fibrosis. Sci Rep, 9, 12561 (2019).

28. Motono, N., Iwai, S., lijima, Y., Usuda, K. \& Uramoto, H. Operative invasiveness does not affect the prognosis of patients with non-small cell lung cancer. BMC Pul Med, 20, 265 (2020).

29. Brinkman, G. L. \& Coates, E. O. The effect of bronchitis, smoking, and occupation on ventilation. Am Rev Respir Dis, 87, 684-693 (1963).

\section{Figures}



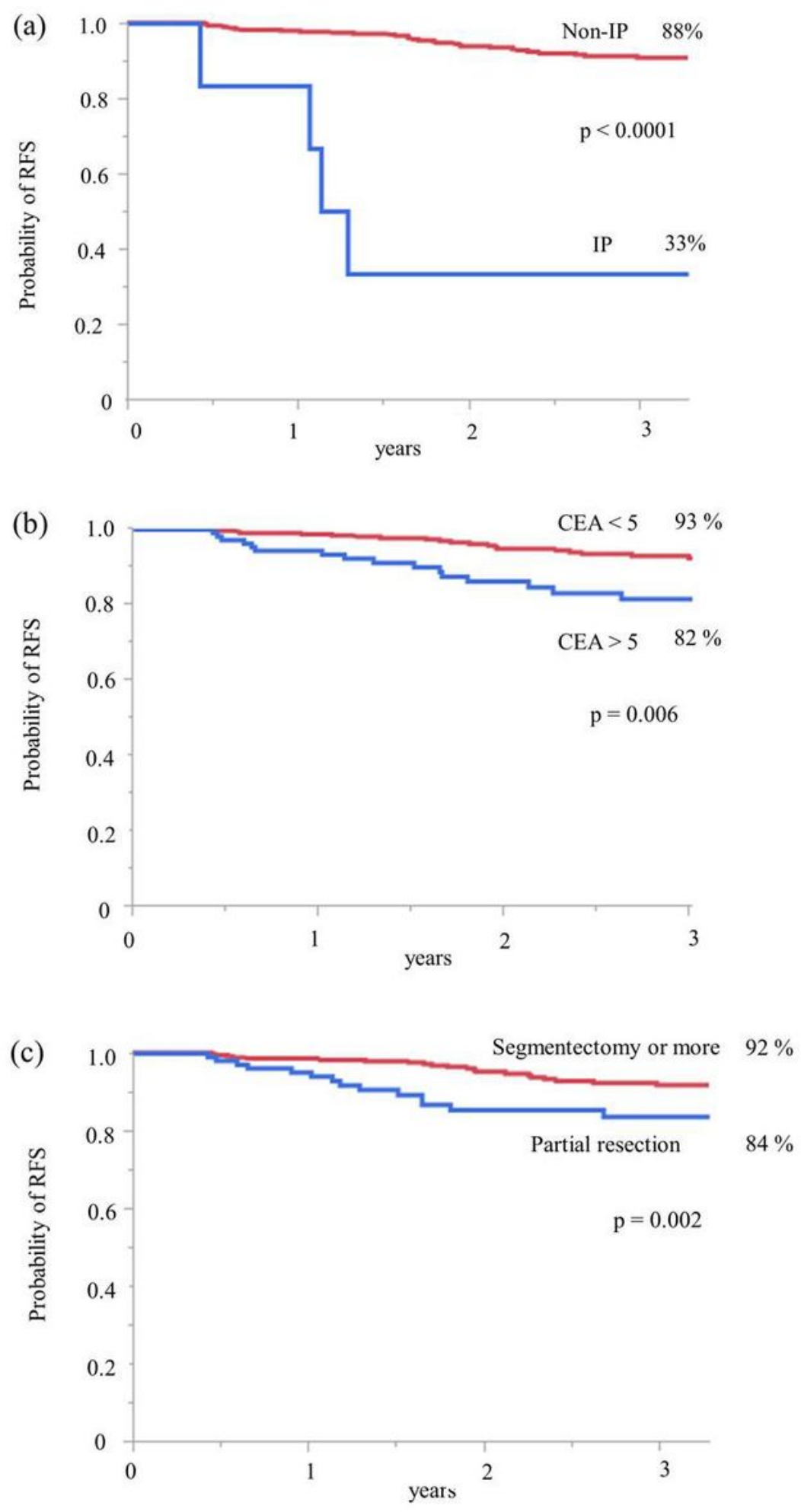

\section{Figure 1}

Relapse-free survival for non-small cell lung cancer patients with pathological stage IA (a) Coexistence of interstitial lung disease group was significantly worse than the absent of interstitial lung disease group. (b) Positive of carcinoembryonic antigen group was significantly worse than negative of carcinoembryonic antigen group. (c) Partial resection group was significantly worse than segmentectomy or lobectomy group. 

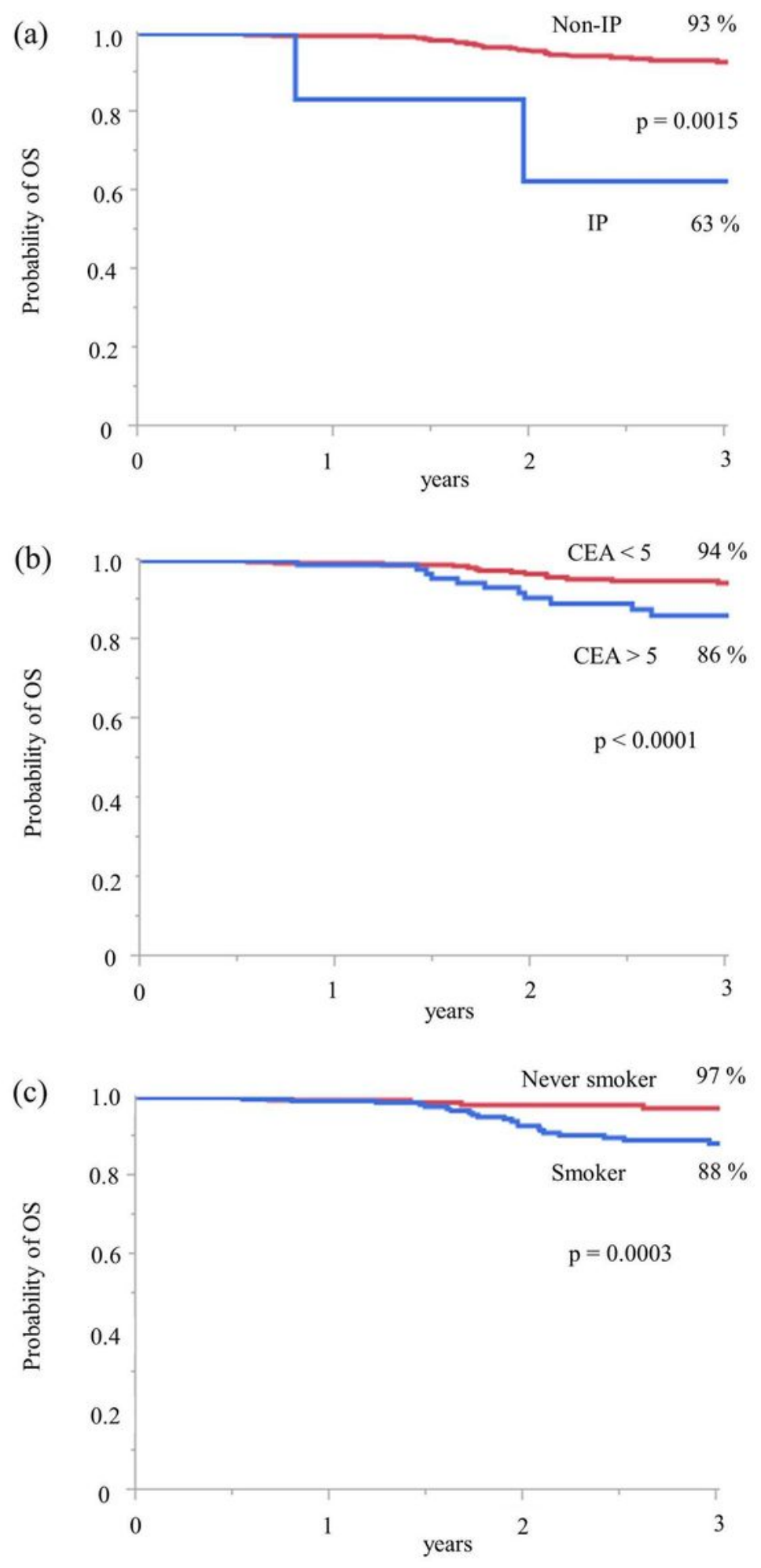

\section{Figure 2}

Overall survival for non-small cell lung cancer patients with pathological stage IA (a) Coexistence of interstitial lung disease group was significantly worse than the absent of interstitial lung disease group. (b) Positive of carcinoembryonic antigen group was significantly worse than negative of carcinoembryonic antigen group. (c) Smoker group was significantly worse than never smoker group. 